Indonesian Journal of Nutrition and Dietetics Vol. 7, No. 2, 2019: 41-50
Available online at: http://ejournal.almaata.ac.id/index.php/IJND DOI : http://dx.doi.org/10.21927/ijnd.2019.7(2).41-50

\title{
Determinants of non-cardiorespiratory fitness in pre-elderly women
}

\author{
Mustakim $^{1}$, Kusharisupeni $^{2}$
}

${ }^{1}$ Faculty of Public Health, University of Muhammadiyah Jakarta, Jalan K.H. Ahmad Dahlan, Cirendeu, Ciputat ${ }^{2}$ Public Health Nutrition Department, Faculty of Public Health, Universitas Indonesia Kampus UI Depok, Jawa Barat ${ }^{*}$ Corresponding author. mustakim.sp76@gmail.com

\begin{abstract}
ABSTRAK
Latar Belakang: Kelompok lanjut usia mengalami perkembangan yang pesat di masa mendatang. Kebugaran menjadi salah satu prediktor dalam menentukan kesakitan dan kematian pada kelompok lansia. Tujuan: Penelitian ini memiliki tujuan untuk membahas karakteristik, komposisi tubuh, gaya hidup dan asupan gizi dengan kebugaran yang diukur melalui serangkaian tes kebugaran pada wanita pralansia di Kecamatan Pancoran Mas kota Depok.

Metode: Penelitian menggunakan desain studi cross-sectional dan dilakukan pada 134 orang wanita pralansia di Kecamatan Pancoran Mas kota Depok.

Hasil: Hasil penelitian menunjukkan bahwa 72,4 persen wanita pralansia berada pada kondisi tidak bugar. Variabel paling berhubungan dengan kebugaran adalah aktivitas fisik setelah dikontrol dengan IMT, persen lemak tubuh, status merokok dan asupan vitamin B12.

Kesimpulan: Akivitas fisik merupakan faktor paling berpengaruh terhadap kebugaran non kardiorespiratori pada wanita pralansia. Oleh karena itu, wanita pralansia wajib menjaga aktivitas fisiknya secara rutin melalui jalan kaki, senam ataupun kegiatan fisik lainnya.
\end{abstract}

KATA KUNCI : wanita pra lansia, kebugaran non kardiorespiratori, aktivitas fisik

\begin{abstract}
Background: Fitness was found as an indicator of morbidity and mortality to the elderly. A person who have low physical fitness level is often associated with a lack of regular physical activities and causes of degenerative diseases and premature death. Besides, fitness will have an inluenfce to his body composition (reduced fat levels in the abdomen), increase lipid profile (reduced triglyceride levels, increased HDL), reduce $L D L$, and reduce blood pressure.

Objectives: This study focused on the physical fitness of middle-aged women in Pancoran Mas, Depok. The purpose of this study was to look at the relationship between lifestyle, body composition and nutritional intake and physical fitness. In addition, this study also determined the dominant factor related to physical fitness.

Methods: This study used a cross-sectional design and the data were collected from 134 middle-aged women. Physical Fitness was measured by fitness test using handgrip test, sit and reach test, and chair sit and stand the test. Data on body composition will be collected through a series of anthropometric measurements. Meanwhile, nutrition intake was collected using an interview questionnaire on a 2-day 24-hour dietary recall and lifestyle were collected by using Physical Activity Scele for Elderly (PASE Questionnaire).

Results: The result showed that 72.4 percent of respondents had a low category level condition. This study showed that there is a significant relationship between physical activities and non-cardiorespiratory fitness in middle-aged women. The dominant factor related to determining fitness was physical activities with OR 2.382 after being measured by a percentage of body fat, body mass index (BMI), smoking status and vitamin B12 intake.

Conclusions: The most influential variable was physical activities after adjusted by BMI (Body Mass Index), the percentage of body fat, smoking status, and vitamin B12 intake.middle aged women should keep their physical activity in active level. They can use walking or aerobic dance to maintain their physical activity.
\end{abstract}

KEYWORDS: Middle-aged women; non-cardiorespiratory fitness; physical activity 


\section{INTRODUCTION}

In developing countries, the increasing number of communicable diseases such as cancer, diabetes mellitus, and heart diseases are considered negative implications of lifestyle changes, poor dietary habits, and aging processes (1). The aging process and health condition are both causally related to the physical fitness of the elderly, including cardiorespiratory fitness, skeletal-muscle fitness, body composition, and metabolism (2). Physical fitness is seen as strongly indicative of morbidity and mortality (3). Person with low category level of fitness are usually associated with the lack of routine physical exercises, which of the causes degenerative diseases and even death; in contrast, physical fitness will positively affect their body composition -- by decreasing visceral fat (4)--, build up lipid profiles (reduced triglyceride levels and increased HDL), and reduce LDL (5). In addition, physical fitness also decreases blood pressure, improves blood circulation (6), and contributes to the increase of people's psycho-social well-being, stress (7).

Based on a study involving about 300.000 adult people aged 15-to-65-year-old respondents from 76 countries, it is known that the percentage of people's physical exercises worldwide has declined to $21.4 \%$ (8). As far as is known, lack of physical exercise can cause the elderly to suffer from degenerative diseases and have problems with their body fitness (9). Research conducted in a local public-health clinic in Arga Makmur, Bengkulu, at the conclusion that $69.4 \%$ of all respondents recorded a low level of physical fitness (10). Using a cross-sectional design, another research in a heart gymnastics club in Duren Sawit, East Jakarta showed almost the same findings by $77.7 \%$ (11). Using the fitness test including Hand Grip Test, Czuka Chair Sit-to-Stand Test, and sit-and-reach test, a preliminary study on the physical fitness of the elderly found a negative result of $84.6 \%$.

Depok is a city surrounding Jakarta with its rapid population growth, especially in the number of the elderly and middle aged group. Based on data of Depok BPS in 20014, it was predicted that the total population in Depok would be about
2.033.551, 266.808 of whom would be middle aged group, and 94.314 will be elderly group people. As we know, middle aged group was one of the group that concerned in low level of fitness status. Many factors are related as caused to their fitness level. As discussed previously showed that sedentary lifestyle, nutrition intake, nutritional status and physical activity are factors related to fitness status. Given the background previously mentioned, this research is aimed at knowing determinants dealing with non-cardiorespiratory fitness of middle-aged women in Pancoran Mas, Depok.

\section{MATERIALS AND METHODS}

This is quantitative research with the design of the cross-sectional study to know determinants dealing with non-cardiorespiratory fitness of middleaged women in Pancoran Mas, Depok. The primary data were collected from April to May 2015.

The data collection include fitness status, characteristics (educational levels), body compositions ((BMI, the body fat percentage, and waist size), lifestyle (smoking status and physical activities), and daily intake of energy, vitamin $B_{12}$ and $D$, and calcium/Ca. The data about physical fitness were obtained through a set of fitness tests, including Handgrip, Czuka Chair Sit to Stand Test dan Sit and Reach Test, and then the results will be converted. The data on body compositions were acquired from a set of anthropometric measurements, physical activity was measured by using Physical Activity Scele for elderly (PASE Questionnaires) and nutrition intake were collected using 2-day 24-hour dietary recall questionnaires.

The target population of this research was all middle-aged women in Pancoran Mas, Depok, West Java in 2015. They were, in turn, considered the population of the research. The eligibility of potential subjects was determined by using inclusion and exclusion criteria. According to the inclusion criterion, the subjects of this research were all middle-aged women, ranging from 45 to 59 years-old ones, in Pancoran Mas, Depok in 2015; meanwhile, the exclusion criteria were 
all middle-aged women in Pancoran Mas, Depok in 2015 with physical problems such as physical disabilities, paralyzes, and disabilities associated with aging processes refused to be involved in the research.

The sample was selected by using the method of probability proportional sampling (PPS). Calculated using a particular formula, the total respondents were 134 women. The data collected were analyzed in the bivariate analysis by using chisquare and in multivariate analysis using a logistic regression model. This study didn't need ethical clearance regarding to data collection did not have big risk to health status of the respondent

\section{RESULTS}

The result of the univariate analysis of determinants related to the fitness of middle-aged women in Pancoran Mas, Depok in 2015 led to some findings shown below.
Table 1 showed that the distribution of the respondents' fitness status was at a low level. Besides, in the category of body compositions including body fat percentage, body mass index, and waist size, they tended to be overweight and even obese. Moreover, most of them were at a low level of physical activity and had inadequate intake of energy, vitamin $\mathrm{D}$ and $\mathrm{B}_{12}$, and calcium.

Table 2 showed the relation between variables and the respondents' fitness status. The variable with a significant relation was physical activities, while any other variables was not significant.

Based on the multivariate analysis with double logistic regression (Table 3), it was known that the variable of physical activities had $p$-value $<0.05$ with Odds Ratio (OR) 2.382, which means after undergoing such tests as body fat percentage, body mass index, smoking status, and intake, middleaged women with higher level of physical activities, were open to being 2.382 times fitter than those with the lower level of physical activities.

Table 1. Distribution of the Overall Result of the Univariate Analysis of Determinants Related to the Fitness of Middle-Aged Women in Pancoran Mas, Depok in 2015

\begin{tabular}{|c|c|c|c|}
\hline Variables & Categories & Total & Percentage (\%) \\
\hline \multirow{2}{*}{ Fitness } & Normal & 37 & 27.6 \\
\hline & Low & 97 & 72.4 \\
\hline \multirow{3}{*}{ Educational Level } & High & 7 & 5.2 \\
\hline & Basic & 127 & 94.8 \\
\hline & Normal (18-23) & 53 & 39.6 \\
\hline Body Mass Index & $\begin{array}{l}\text { Underweight }(<18) \\
\text { Overweight }(>23)\end{array}$ & 81 & 60.4 \\
\hline \multirow{2}{*}{ Body Fat Percentage } & Normal $(<25 \%)$ & 23 & 17.2 \\
\hline & Higher (>25\%) & 111 & 82.8 \\
\hline \multirow{2}{*}{ Waist Size } & Normal $(<88$ cm) & 37 & 27.6 \\
\hline & At-Risk (>88 cm) & 97 & 72.4 \\
\hline \multirow{2}{*}{ Physical Activities } & Active & 41 & 30.6 \\
\hline & Inactive & 93 & 69.4 \\
\hline \multirow{2}{*}{ Smoking Status } & Active Smoker & 14 & 10.4 \\
\hline & Non-Smoker & 120 & 89.6 \\
\hline \multirow{2}{*}{ Energy Intake } & Adequate & 23 & 17.2 \\
\hline & Inadequate & 111 & 82.8 \\
\hline \multirow{2}{*}{ Vitamin D Intake } & Adequate & 25 & 18.7 \\
\hline & Inadequate & 109 & 81.3 \\
\hline \multirow{2}{*}{ Vitamin $B_{12}$ Intake } & Adequate & 26 & 19.4 \\
\hline & Inadequate & 108 & 80.6 \\
\hline \multirow{2}{*}{ Calcium Intake } & Adequate & 4 & 3 \\
\hline & Inadequate & 130 & 97 \\
\hline
\end{tabular}


Table 2. Distribution of the Overall Result of the Bivariate Analysis of Determinants Related to Fitness of Middle-Aged Women

\begin{tabular}{|c|c|c|c|c|c|c|c|}
\hline \multirow{3}{*}{ Variables } & \multirow{3}{*}{ Categories } & \multicolumn{4}{|c|}{ Fitness } & \multirow[t]{3}{*}{ P-value } & \multirow[t]{3}{*}{$\begin{array}{c}\text { OR } \\
(95 \% \mathrm{Cl}) \\
\end{array}$} \\
\hline & & \multicolumn{2}{|c|}{ Low } & \multicolumn{2}{|c|}{ Normal } & & \\
\hline & & $\mathrm{N}$ & $\%$ & $\mathrm{~N}$ & $\%$ & & \\
\hline \multirow{2}{*}{ Educational Level } & Basic & 94 & 74 & 33 & 26 & 0.073 & $\begin{array}{c}3.79 \\
0.807-17.86\end{array}$ \\
\hline & High & 3 & 42.9 & 4 & 57.1 & & \\
\hline \multirow[t]{2}{*}{ Boddy Mass Index } & $\begin{array}{c}\text { Underweight or } \\
\text { Overwirght }\end{array}$ & 56 & 69.1 & 25 & 30.9 & 0.298 & $\begin{array}{c}0.656 \\
0.295-1.456\end{array}$ \\
\hline & Normal Weight & 41 & 77.4 & 12 & 22.6 & & \\
\hline \multirow{2}{*}{$\begin{array}{l}\text { Body Fat } \\
\text { Percentage }\end{array}$} & Higher & 80 & 72.1 & 31 & 27.9 & 0.857 & $\begin{array}{c}0.911 \\
0.329-2.523\end{array}$ \\
\hline & Normal & 17 & 73.9 & 6 & 26.1 & & \\
\hline \multirow[t]{2}{*}{ Waist Size } & Risk & 69 & 71.1 & 28 & 28.9 & 0.599 & $\begin{array}{c}0.792 \\
0.332-1.891\end{array}$ \\
\hline & Normal & 28 & 75.7 & 9 & 24.3 & & \\
\hline \multirow[t]{2}{*}{ Physical Activities } & Inactive & 73 & 78.5 & 20 & 21.5 & 0.017 & $\begin{array}{c}2.585 \\
1.168-5.721\end{array}$ \\
\hline & Active & 24 & 58.5 & 17 & 41.5 & & \\
\hline \multirow[t]{2}{*}{ Smoking Status } & Active Smoker & 12 & 85.7 & 2 & 14.3 & 0.239 & $\begin{array}{c}0.405 \\
0.086-1.903\end{array}$ \\
\hline & Non Smoker & 85 & 70.8 & 35 & 29.2 & & \\
\hline \multirow[t]{2}{*}{ Energy Intake } & Inadequate & 80 & 72.1 & 31 & 27.9 & 0.857 & $\begin{array}{c}0.911 \\
0.329-2.523\end{array}$ \\
\hline & Adequate & 17 & 73.9 & 6 & 26.1 & & \\
\hline \multirow[t]{2}{*}{ Vitamin D Intake } & Inadequate & 80 & 73.4 & 29 & 26.6 & 0.586 & $\begin{array}{c}1.298 \\
0.506-3.329\end{array}$ \\
\hline & Adequate & 17 & 68 & 8 & 32 & & \\
\hline \multirow{2}{*}{ Vitamin $\mathrm{B}_{12}$ Intake } & Inadequate & 81 & 75 & 27 & 25 & 0.168 & $\begin{array}{c}1.875 \\
0.761-4.622\end{array}$ \\
\hline & Adequate & 16 & 61.5 & 10 & 38.5 & & \\
\hline \multirow[t]{2}{*}{ Calcium Intake } & Inadequate & 94 & 72.3 & 36 & 27.7 & 0.906 & $\begin{array}{c}0.870 \\
0.088-8.643 \\
\end{array}$ \\
\hline & Adequate & 3 & 75 & 1 & 25 & & \\
\hline
\end{tabular}

Table 3.

\begin{tabular}{|c|c|c|}
\hline Variables & P Value & $\begin{array}{c}\text { OR } \\
(95 \% \mathrm{Cl})\end{array}$ \\
\hline Physical Acivities & 0.039 & $\begin{array}{c}2.382 \\
(1.044-5.436)\end{array}$ \\
\hline Smoking Status & 0.227 & $\begin{array}{c}0.349 \\
(0.063-1.921)\end{array}$ \\
\hline Body Fat Percentage & 0.433 & $\begin{array}{c}1.632 \\
(0.480-5.556)\end{array}$ \\
\hline IMT & 0.257 & $\begin{array}{c}0.577 \\
(0.223-1.493)\end{array}$ \\
\hline Vitamin $\mathrm{B}_{12}$ Intake & 0.125 & $\begin{array}{c}(2.210) \\
0.803-6.082\end{array}$ \\
\hline
\end{tabular}

\section{DISCUSSIONS}

According to the fitness test, the fitness status of middle-aged women in Pancoran Mas, Depok in 2015 was at a low level $(72.4 \%)$. The finding of this research was almost the same as that of a crosssectional study in the heart gymnastics club in Duren Sawit, West Jakarta (70.7\%). In the latter, the fitness test used the indicator of cardiorespiratory capacity $\left(\mathrm{VO}_{2} \max \right)$. the test took 6 minutes, and the result was then converted into fitness value (11).

This research differed from that of Mulyadi (2005) and that of Harmani and Mansyur (2013) in the use of indicators for fitness status. This research 
took 3 aspects as the indicators for fitness: muscular strength, flexibility, and energy; meanwhile, the other two used only one aspect: cardiorespiratory endurance $\left(\mathrm{VO}_{2} \mathrm{max}\right)$, thereby being incapable of measure fitness comprehensively $(11,12)$. However, this research reported an important finding to which we must give attention. It found it was surprising that the respondents in their middle age had a low level of fitness status. Fortunately, this could be such an ominous warning that they can prepare everything for their healthier old age. Besides, the finding of this research was insignificantly different from that of the preliminary research in that both found that the middle-aged women were at a low level of fitness status (84.6\%).

Corbin et al., (2001) stated that fitness can help produce great performance (12), so it is true that it is a major factor to be taken into account to enjoy excellent health in old age. Rudman (1989) supported that fitness can help old people perform physical activities, make a social response to their surroundings and prevent them from being stressed (13). Additionally, the results of the fitness in this research found that educational levels are significantly related to fitness status. This confirmed the preliminary hypothesis concerning the relationship between educational levels and fitness.

Similarly, according to WHO (1999), educational levels constitute one of the external factors in measuring fitness, education is someone's rational reason for his/her action; the lower the educational levels of people achieve, the sooner they suffer disabilities or premature death. Education can help them to be independent and self-confident. A longitudinal study states that educational levels accurately predict death often preceded by social and psychological factors and impact to their physical fitness in performing activities (14). In contrast, another research reported that there was no significant relationship between educational levels and fitness status (11).

The relation between body mass index and fitness status, meanwhile, proved insignificant, which contrasted with the preliminary hypothesis about it. Also, this was quite the opposite of the research on old people in the Caucasian population, finding that body mass index (BMI) was the determining factor in measuring fitness status, whose indicator in this research was cardiorespiratory fitness (Lakoski, et al., 2011).

Another research on middle-aged and old women in Hongkong, China, also supported that body composition, in this case, body mass index, was a causal determinant of fitness $\left(\mathrm{VO}_{2}\right.$ max $)$ by applying a cycle ergometer test (14). A longitudinal study on 1467 middle-aged and old women showed that body mass index was closely related to fitness levels measured by cardiorespiratory fitness (15).

A number of studies were used more effective tools in the measurement of body composition. Body mass index is usually used to predict one's physical abilities (16). Recently, body mass index has not been a direct method of measuring fat percentage. It is associated with old women's performance in completing a job (17). In particular, obese and overweight women produced weaker performances when undergoing such fitness tests as timed up and go task dan walking test those in the normal category $(18,19)$. Brady's study showed that old women with normal body mass index produced a better performance in overall fitness tests than obese and overweight ones (20). In the meantime, our research arrived at a conclusion that middle-aged women with overweight body mass index attained fuller fitness than those with a normal body mass index.

Contrary to its preliminary hypothesis, this research showed no significant relationship between body fat percentage and fitness status. Moreover, this contradicted the theory of Greenberg et al., (2004) that body fat percentage is closely related to fitness status. The higher the percentage of body fat, especially in the middle-aged women, will decrease the mass of muscle quickly. It will be in turn followed by a decrease in muscular strength, which is one of the indicators of fitness status. Furthermore, the body fat percentage is reversely related to physiological performances. In short, it can negatively affect body endurance, one of the main components of fitness (21).

On the other hand, another surprising result achieved in this research dealt with the relation between the waist size and fitness status, in which 
the final result nullified the hypothesis that waist size bears a close relation to fitness status. On the other hand, a case study in England in middle-aged women and men found that grip strength, as one of the fitness indicators, showed a significant relation between waist size and fitness. In this research, the respondents with the normal waist size had more powerful muscular strength, in this case, their grip strength, than those with nonstandard waist size (at risk) (22). In addition, research involving 2092 middle-aged men and women suggested that body composition has a close relation to someone's fitness - physical performances and physical limitations (23). Likewise, some other research considered waist size to be indicative of some functional disorders for the elderly (24).

The absence of the significant relation of body mass index, body fat percentage and waist size to fitness status resulted from other determinants. It was clear that most respondents were considered obese, or overweight. Meanwhile, those fitness tests require the examinee to have the flexibility and strong lower body parts; it is undoubtedly difficult for obese middle-aged women to successfully undergo the test. What is more, the status of the physical activities of those women, either of the normal category or of an overweight category (at risk), seemed to be low in all the three variables. Subsequently, the research indicated that the status of physical activities and the fitness status had a close, significant relation, just as predicted in the preliminary hypothesis.

This finding is supported by another research on 51-to-59-year-old women, suggesting that physical activities have a significant relation to health and longevity (25). According to the theory of Chodzko-Zajko in Carlsson (2011), lack of physical activities make a poor condition for middle-aged women which is important to avoid. Given the fact that they have the lower number, strength, and energy of the muscles than men do, making them nearest to the limited value of the loss of dependence on $A D L$ (26). Women, as also reported by some research, have difficulty adding their muscle mass even after doing physical exercises. Besides that, an exercise routine can build up physical fitness which in turn initiates a scheme for primary and secondary prevention of degenerative diseases. Those with high level of physical activity will be at low risk of being sick (27).

The finding of this research also similar with other statements that physical activities are one of the fundamental aspects of someone's fitness level and that they can slow down the aging process indicated by the decrease in an aerobic workout, muscular strength, and, at last, fitness level (28). Besides, in their study, Keysor dan Jette (2001) insisted that old and middle-aged people do specific physical exercises so as to increase their strength, aerobic workout, flexibility, walking, and balance (29). To serve this purpose, the provision of professional trainers for primary health services for them as well as printed, supplemental materials is fairly effective (30).

As to the relation between smoking status and fitness, this research showed no significant relation between smoking status and fitness status of middle-aged women in Pancoran Mas, Depok in 2015. On the contrary, a cross-sectional study showed that smoking status has something to do with impaired body function. (Lacorix et al., 1993 Dalam Rapuri et al., 2007) (31). Similarly, Rapuri et al., (2006) stated that smoking status is a risk factor for the decrease in middle-aged women's muscular strength, which is one the components of physical fitness, and in turn in their physical activities. Using a prospective study, the research involving a group of 51-to-59-year-old people showed that lifestyle choices such as smoking are closely related to the health and longevity of the old (25).

This research also produced a negative result of the relation between fitness status and nutrient intake, energy. This invalidated the preliminary hypothesis that there is a significant relationship between nutrient intake and fitness of middle-aged women in Pancoran Mas, Depok in 2015. The elderly gradually have a change in their energy needs, for they experience a decrease in total energy consumption. They need an energy boost to carry out some physiological function either when performing physical activities for health maintenance or when taking a rest (32). Middle-aged people, 
meanwhile, need adequate energy to avoid nutrient deficiency and other health problems such as muscle fatigue, breathing difficulty, and higher risk for death. Therefore they need an energy boost in order to perform frenetic physical activities and keep healthy (33).

Energy was needed for body metabolism, physiological functions, muscle activities, production of body heat, growth, and new synthetic tissues. The energy need of the elderly and the middleaged people is hard to fulfill because of their agingprocess-related problems including physiological changes and changes in their health status and lifestyle which subsequently decrease their food intake (34). The middle-aged women in this research had low energy intake, so they had to increase it quickly. According to a study, nutritional supplements containing energy and protein are effective enough to enhance the functional status of the elderly, especially those whose nutrient status tends to be at risk (35).

Based on the standard value of the fitness test in this research, there was no significant relationship between the status of vitamin $D$ intake and that of fitness. This was in contrast to its preliminary hypothesis receiving positive results.

Another contrast was provided by research on the elderly suggesting that vitamin $D$ in the form of 25-hydroxyvitamin D ( $25 \mathrm{OHD}$ ) forms a closer association with the endurance and function of the muscles (36). However, other research on the elderly concerning the low intake of serum 25-hydroxyvitamin $D$ showed that muscular strength has nothing to do with fitness (37). Vitamin D theoretically contributes to muscular strength; those suffering from vitamin $D$ deficiency will experience muscle fatigue and be at risk of osteoporosis (38). Middle-aged women need to maintain an adequate intake of vitamin D to avoid an accidental fall, as suggested in some research that vitamin D3 along with calcium intake is moderately effective in avoiding sustaining fracture, thereby circumventing functional problems and reducing the risk of a nasty fall (39). Vitamin $D$ is a fat-soluble vitamin that serves as hormones and preserves an even balance between calcium and phosphates for optimization of bone mass and muscle function. The deficiency of vitamin $D$ is known as one of the main causes of osteoporosis dan osteomalacia. It is stated in some research that vitamin $D$, whether or not it contains calcium, can prevent the elderly and middle-aged people from such functional disorders as an accidental fall (Cameron et al., 2010 Dalam Ministry of Health, 2013)(34).

According to the standard value of the fitness test of this research, the intake of vitamin $B_{12}$ bore no close relation to fitness status, which is contrary to its preliminary hypothesis suggesting otherwise.

Vitamin $B_{12}$ is theoretically a component of nutrient intake directly related to fitness. Vitamin $B_{12}$ is known to have a function of DNA synthesis, red blood cell formation, and neurological function. The deficiency of vitamin $B_{12}$ will affect cardiorespiratory and cognitive health, neurological changes, reduced strength of muscles, and functional disabilities (40). Deficiency of vitamin $B_{12}$ was associated to reduced of energy, physical exercise intolerance, fatigue, rapid breathing, and palpitation (NHMRC, 2006 in Ministry of Health, 2013) (34).

There was no close relation between calcium intake and fitness status according to the standard value of the fitness test of this research. In contrast, its preliminary hypothesis showed a close relationship between both.

This finding also challenged the theory that suggests that calcium essential for muscle contraction and the nerve transmission is closely related to fitness (41). Besides, middle-aged women who, for the purpose of osteoporosis prevention, take a calcium supplement with cardiovascular risk can avoid functional disorders (42). Calcium is essentially needed for the growth and maintenance of bones in its use for neuromuscular function and heart function. Calcium is found in bones and teeth, so low calcium intake leads to bone density decline and even osteoporosis. Osteoporosis in menopausal women, either old or middle-aged women, often cause fracture and even death, despite other contributing factors like lack of physical exercise and vitamin D intake (34).

According to Table 3, the major, significant factor in this research is physical activities with 
the value of OR 2.382 after measured by body fat percentage, body mass index, smoking status, and vitamin $B_{12}$ intake. The result defined that after measured by body fat percentage, body mass index, smoking status, and vitamin $\mathrm{B}_{12}$ intake, middle-aged women with a high level of physical activities are open to being fitter 2.382 times than those with a low level of physical activities.

Nutrient intake was not associated with non cardiorespiratory fitness may be caused differences in perception when filling 24 hour recall questionnaire. It allows the calculation being ambiguous in nutrient intake. In addition, 24 hour recall method is very dependent on the memory of the respondent so that possibility of remembering food intake that has been eaten is not easy.

\section{CONCLUSION AND RECOMMENDATION}

This research showed the significant relationship between the variable of physical activities and middle-aged women in Pancoran Mas, Depok in 2015. the major, significant factor in this research is physical activities with the value of OR 2.382 after measured by body fat percentage, body mass index, smoking status, and vitamin $B_{12}$ intake in middle-aged women in Pancoran Mas, Depok in 2015.

Given the fitness status, in which more than $70 \%$ of middle-aged women are in the low level of fitness, Public Health Office of Depok realized the importance of taking some efforts to help middleaged women enhance their fitness, including complete the existing health program, called making Depok the elderly-care city, in which there have been 12 public health centers for the elderly from which they can benefit. Other programs include providing facilities and infrastructures like active, beautiful outdoor parks for such physical exercises as gymnastics, walking, and running. Public Health Office of Depok also plans to make government intervention to maintain Depok recidents' fitness by conducting tests for public fitness and nutrient intake.

Such programs can help POSBINDUs (Pos Pembinaan Terpadu) to design innovations in their routine practices. POSBINDU is one of program from Puskesmas (Public Health Services) which designed for middle aged and elferly group to maintain their health status. It is recommended for Posbindu for the elderly to initiate modest exercise programs or competitions among posbindus. As an illustration, posbindus may invite professional trainers to take routine physical exercises in association with particular components to be trained using FITT (frequency, intensity, time and type) method. For example, those who suffer from calcium deficiency or osteoporosis do gymnastics for osteoporosis. In addition to exercise programs, posbindus can promote public education about the urgency of adequate nutrient intake for the elderly and middle-aged people.

It is important for further research on fitness of middle-aged women to administer fitness test so comprehensively that it can measure overall essential components of fitness of middle-aged women and give accurate, updated information for validation studies of fitness tests in the future. Other detailed recommendations to consider include adding new variables like middle-aged men, Basic Activities of Daily Living (BADL) and Instrumental Activities of Daily Living (IADL) in relation to personal independence of the elderly and abdominal circumference. Educational levels needs to be considered important variables to test how perfectly well people know the importance and effect of fitness, thus producing reference material for local public health officers in conducting an intervention program.

\section{REEFRENCES}

1. World Health Organization. WHO | Good health adds life to years. WHO. 2015;

2. Sirard JR, Pate RR. Physical activity assessment in children and adolescents. Vol. 31, Sports Medicine. Adis International Ltd; 2001. p. 439-54.

3. Blair SN, Brodney S. Effects of physical inactivity and obesity on morbidity and mortality: current evidence and research issues. Med Sci Sport Exerc [Internet]. 1999 Nov;31(Supplement 
1):S646. Available from: http://journals.Iww. com/00005768-199911001-00025

4. Maiorana A, O'Driscoll G, Taylor R, Green $D$. Exercise and the Nitric Oxide Vasodilator System. Vol. 33, Sports Medicine. Sports Med; 2003. p. 1013-35.

5. Berg A et al. Physical Activity and Lipoprotein Metabolism: Epidemiological Evidence and Clinical Trials - PubMed [Internet]. Available from: https://pubmed.ncbi.nlm.nih.gov/9182653/

6. Hambrecht R, Wolf A, Gielen S, Linke A, Hofer $J$, Erbs S, et al. Effect of exercise on coronary endothelial function in patients with coronary artery disease. N Engl J Med. 2000 Feb 17;342(7):454-60.

7. Warburton DER, Gledhill N, Quinney A. Musculoskeletal fitness and health. Can J Appl Physiol. 2001;26(2):217-37.

8. Dumith SC, Hallal PC, Reis RS, Kohl HW. Worldwide prevalence of physical inactivity and its association with human development index in 76 countries. Prev Med (Baltim). 2011 Jul;53(1-2):24-8.

9. Vogel T, Leprêtre PM, Brechat PH, Lonsdorfer E, Benetos A, Kaltenbach G, et al. Effects of a short-term personalized intermittent work exercise program (IWEP) on maximal cardiorespiratory function and endurance parameters among healthy young and older seniors. J Nutr Heal Aging. 2011 Dec 13;15(10):905-11.

10. Mulyadi M. Hubungan asupan zat gizi dengan tingkat kebugaran usia lanjut kelompok binaan Puskesmas di Kecamatan Kota Arga Makmur Kabupaten Bengkulu Utara. 2005;

11. Harmani AR, Mansyur M. "Peran indeks massa tubuh, tanda vital dan sosiodemografi terhadap kebugaran peserta klub jantung sehat, jakarta timur." J Kedokt Indones. 2013;1 (3).

12. Hubungan asupan zat gizi dengan tingkat kebugaran usia lanjut kelompok binaan Puskesmas di Kecamatan Kota Arga Makmur Kabupaten Bengkulu Utara - repository civitas UGM [Internet]. [cited 2020 Jun 12]. Available from: https://repository.ugm.ac.id/66502/

13. Rudman D. "Nutrition and fitness in elderly people." Am J Clin Nutr. 1989;49;1090-8.
14. Yu R, et al. "Cardiorespiratory fitness and its association with body composition and physical activity in hong kong chinese women aged from 55 to 94 years." Maturitas. 2011;69:348-53.

15. Sui $X$, et al. "Physical activity/fitness peaks during perimenopause and bmi change patterns are not associated with baseline activity/fitness in women: a lonitudinal study with a median 7-year follow-up." Br J Sport Med. 2013;47:77-83.

16. Jankowski CM, et al. "Relative contributions of adiposity and muscularity to pyhsical function in community dewlling older adults." Obesity. 2008;16 (5):1039-44.

17. Fragala M, et al. "Gender differences in anthropometric predictors of physical performance in older adults." Gend Med. 2012;9 (6):445-6.

18. Riebe $D$, et al. "The relationship between obesity, physical activity, and physical function in community dwelling older adults." Obesity. 2008;16 (5):1039-44.

19. Woo J, et al. "BMI, body composition, and physical functioning in older adults." Obesity. 2007;15(7):1886-94.

20. Brady A., et al. "Impact of body mass index on the relationship between muscle quality and physical function in older women." J Nutr Heal Aging. 2014;18, Number.

21. Greenberg JS, Dintiman GB, Myers Oakes B. Physical fitness and wellness : changing the way you look, feel, and perform. Human Kinetics; 2004. 509 p.

22. Keevil V., et al. "Cross sectional associations between different measures of obesity and muscle strength in men and women in a british cohort study." J Nutr Heal Aging 2014. 2015;19 (1).

23. Sternfeld B, et al. "Associations of body composition with physical performance and selfreported functional limitation in elderly men and women." Am J Epidemiol. 2002; Volume 156.

24. Na YM, et al. "Obesity, Obesity Related Disease, and Disablity." Korean J Fam Med. 2011;32:412-22.

25. Heir T, Erikssen J, Sandvik L. Life style and longevity among initially healthy middle-aged 
men: Prospective cohort study. BMC Public Health [Internet]. 2013 Dec 11;13(1):831. Available from: http://bmcpublichealth.biomedcentral. com/articles/10.1186/1471-2458-13-831

26. Carlsson M. Nutritional Status, Boy Composition, and Physical Activity Among Older People Living in Residential Care Facilities. Sweden: Department of Community Medicine and Rehabilitation, Geriatric Medicine; 2011.

27. Warburton D, Gledhill N, Quinney A. "Musculoskeletal fitness and health." Can J Appl Physiol. 2001;26:217-37.

28. Astrand P-O. "Physical Activity and Fitness." Am J Clin Nutr. 1992;1231S-6S(55).

29. Keysor J., Jette A. "Have we oversold the benefit of late-life exercise?" J Gerontol A Biol Sci Med Sci. 2001;56 (7):M412-23.

30. Eakin E., et al. "Review of primary carebased physical activity intervention studies: effectiveness and implications for practice and future research". J Fam Prat. 2000;49 (2):68158.

31. Rapuri PB, Gallagher JC, Lynette MS. "Smoking is a risk factor for decreased physical performance in elderly women." J Gerontol Med Sci. 2007; Vol. 62A,:93-100.

32. Oliveira M., K.C F, V.A L-M. "Nutritional status and functional capacity of hospitalized elderly." Nutr J. 2009;8:54.

33. Milne A., et al. "Protein and energy supplementation in elderly people at risk from malnutrition." Cochrane Database Syst Rev. 2009;(2):CD0032.
34. of Health M. Food and Nutrition Guidelines for Healthy Older People: A background paper [Internet]. Available from: www.health.govt.nz

35. Milne A.C, et al. "Protein and energy supplementation in elderly people at risk from malnutrition." Cochrane Database Syst Rev. 2005;1.

36. Mastaglia S., et al. "Effect of vitamin d nutritional status on muscle function and strength in healthy women aged over sixty-five years." $J$ Nutr Heal Aging. 2011; Volume 15,.

37. Annweiler $C$, et al. "Is there an association between serum 25-hydroxivitamin D concentration and muscle strength among older women? results from baseline assesment of the epidos study." J Nutr Heal Aging. 2009;13 Number.

38. Makariou S, Liberopoulos E, Elisaf M, Challa A. Novel roles of vitamin d in disease: what is new in 2011? Eur J Int Med. 2011;22 (4):355-62.

39. Riboli E, Norat T. "Epidemiologic evidence of the protective effect of fruit and vegetables on cancer risk." Am J Clin Nutr. 2003;78(3 Suppl.

40. Fatmah. Gizi usia lanjut. Jakarta: Penerbit Erlangga; 2010.

41. Bauer DC. "Calcium supplements and fracture prevention." N Engl J Med. 2013;369 (16):1.

42. Bolland MJ, Avenell A, Baron JA, Grey A, MacLennan GS, Gamble GD, et al. Effect of calcium supplements on risk of myocardial infarction and cardiovascular events: metaanalysis. Bmj. 2010;341(jul29 1):c3691-c3691. 